\title{
DISTRIBUSI SPASIO TEMPORAL KELIMPAHAN DAN BIOMASSA FITOPLANKTON DALAM KAITANNYA DENGAN POTENSI PRODUKSI IKAN DI WADUK IR. H. DJUANDA, JAWA BARAT
}

\author{
Endi Setiadi Kartamihardja ") dan Adriani Sri Nastiti Krismono*)
}

\begin{abstract}
ABSTRAK
Fitoplankton sebagai produser primer berperan penting dalam siklus energi di suatu perairan waduk atau danau. Distribusi spasio-temporal kelimpahan dan biomassa fitoplankton menggambarkan karakteristik umum suatu badan air dan dapat digunakan untuk menaksir potensi produksi ikannya. Penelitian ini bertujuan untuk mengetahui distribusi spasio-temporal kelimpahan dan biomassa fitoplankton dalam kaitannya dengan potensi produksi ikan di Waduk Ir. H. Djuanda, Jawa Barat. Pengambilan contoh plankton dilakukan setiap bulan di empat stasiun yang mewakili seluruh perairan waduk pada kolom eupotik, yaitu permukaan air, kedalaman 1 , $2,3,4$, dan $5 \mathrm{~m}$, selama delapan bulan. Contoh fitoplankton diambil menggunakan Van Dorn water sampler volume 3 liter yang disaring dengan jaring plankton ukuran mata $25 \mu \mathrm{m}$ menjadi $35 \mathrm{ml}$. Identifikasi genus fitoplankton dilakukan di laboratorium dengan menggunakan mikroskop. Kelimpahan fitoplankton dihitung menggunakan metoda Lackey Drop Microtransect Counting, dan biomassa dihitung berdasarkan kandungan klorofil-a. Potensi produksi ikan ditaksir secara empiris berdasarkan hubungan logaritmik dengan kandungan klorofil-a perairan. Hasil penelitian menunjukkan bahwa di Waduk Ir. H. Djuanda ditemukan sebanyak 30 genera fitoplankton yang termasuk ke dalam kelas Cyanophyceae 9 genera, Chlorophyceae 11 genera, Bacillariophyceae 8 genera, dan Dinophyceae 2 genera. Kelimpahan fitoplankton berkisar antara $2,86 \times 10^{5}$ $2,09 \times 10^{6}$ sel/l yang didominasi kelas Chlorophyceae, Bacillariophyceae, dan Cyanophyceae di mana kelimpahan tertinggi terjadi pada bulan Oktober dan terendah pada bulan Desember. Kelimpahan fitoplankton tertinggi terdapat di stasiun pemasukan air Sungai Citarum atau pengeluaran Waduk Cirata. Biomassa fitoplankton berkisar antara $1621,40 \pm 552,08 \mathrm{mg} / \mathrm{m}^{2}$ dan $807,35 \pm 174,20 \mathrm{mg} / \mathrm{m}^{2}$ dengan biomassa tertinggi terjadi pada bulan Mei dan terendah pada bulan September. Berdasarkan kandungan khlorofil-a fitoplankton, potensi produksi ikan Waduk Djuanda berkisar antara 132,7-300,1 kg/ha/th dengan rata-rata 198,3 $\pm 60,5$ $\mathrm{kg} / \mathrm{ha} / \mathrm{th}$ atau 1.646 ton/th, sedangkan hasil tangkapan aktual pada tahun 2002 sebesar 425 ton atau rata-rata sekitar $51 \mathrm{~kg} / \mathrm{ha}$. Waduk Djuanda dapat diklasifikasikan ke dalam perairan eutrofik-hipereutrofik sehingga potensial untuk pengembangan perikanan tangkap. Transfer efisiensi trofik dari biomassa fitoplankton menjadi biomassa ikan dapat dilakukan dengan cara penebaran ikan pemakan plankton.
\end{abstract}

ABSTRACT: Spatio-temporal distribution of the density and biomass of phytoplankton in relation to fish potential yield of the Ir. H. Djuanda Reservoir, West Java. By: Endi Setiadi Kartamihardja and Adriani Sri Nastiti Krismono

In term of the primary production, phytoplankton has an important role in energy cycle of the reservoir or lake. Spatio-temporal distribution of the density and biomass of phytoplankton represent general characteristics of the water body and might be used to estimate the fish potential yield. A study aimed to investigate spatio-temporal distribution of the phytoplankton density and its biomass in relation to the fish potential yield was conducted in Ir. H. Djuanda Reservoir, West Java. Phytoplankton sampling was done monthly during eight months at four stations representing the reservoir of euphotic water column, i.e. at the water surface, 1, 2, 3, 4, and $5 \mathrm{~m}$ depth. Phytoplankton samples were taken using Van Dorn water sampler of the 3 liters volume filtered upon net of $25 \mu \mathrm{m}$ diameter to be $35 \mathrm{ml}$ of filtrat. Phytoplankton was identified in laboratory using a light microscope. The density was calculated using Lackey Drop Microtransect Counting method and the biomass was calculated based on the chlorophyll-a content. The fish potential yield was estimated empirically from the logarithmic relationship of the chlorophyll-a content. The results show that there are 30 genera of the phytoplankton: 9 genera of class Cyanophyceae, 11 genera of Chlorophyceae, 8 genera of Bacillariophyceae, and 2 genera of Dinophyceae. The phytoplankton density ranged from $2.86 \times 10^{5}$. $2.09 \times 10^{6}$ cell/ that dominated by Chlorophyceae, Bacillariophyceae, and Cyanophyceae. The highest density was found in October at the inlet of the Citarum River or outlet of the Cirata Reservoir station and the lowest density was found in December. The phytoplankton biomass ranged from $1621.4 \pm 552.08 \mathrm{mg} / \mathrm{m}^{2}$ to $807.35 \pm 174.20 \mathrm{mg} / \mathrm{m}^{2}$ with the highest biomass found in May and the lowest biomass found in September. The reservoir was classified into eutro-hypertrophic lake with the fish potential yield ranging from 132.7-300.1 $\mathrm{kg} / \mathrm{ha} / \mathrm{yr}$ (average of $198.3 \pm 60.5 \mathrm{~kg} / \mathrm{ha} / \mathrm{yr}$ or 1,646 ton/yr), while in 2002 the actual fish yield was 425 ton or 51 $\mathrm{kg} / \mathrm{ha}$. It suggests that the reservoir would be potential for capture fisheries development. Transfer of tropic efficiency from phytoplankton biomass to fish biomass might be done by introducting plankton feeder fishes.

KEYWORDS: spatio-temporal distribution, density, biomass, phytoplankton, fish potential yield, Ir. H. Djuanda Reservoir

\footnotetext{
$\therefore$ Peneliti pada Pusat Riset Perikanan Tangkap, Jakarta

-) Peneliti pada Loka Riset Pemacuan Stok Ikan, Jatiluhur
} 


\section{PENDAHULUAN}

Di dalam ekosistem akuatik, struktur populasi fitoplankton berubah sangat dinamis sedangkan komposisi jenis dan distribusi biomassanya berubah secara konstan. Pengetahuan tentang struktur komunitas fitoplankton akan sangat berguna jika dapat diketahui perbedaan antara perubahan populasi dengan variasi distribusi baik secara temporal maupun spasial. Perubahan dalam komposisi jenis dan biomassa tersebut akan berpengaruh terhadap laju fotosintesis, efisiensi asimilasi, laju pemanfaatan unsur hara, dan laju grazing (Wetzel \& Likens, 2000).

Produksi primer dalam pengertian pembentukan material organik merupakan bagian terbesar dari produksi di danau atau waduk yang dilakukan oleh fitoplankton. Meskipun makrofita sebagai salah satu produsen primer mungkin merupakan standing crop yang substansial, namun fitoplankton pada umumnya mempunyai laju turnover yang lebih cepat. Produksi primer menggambarkan sintesis bahan organik dalam sistem akuatik dan proses total fotosintesis dengan bagan alir metabolisme yang kompleks.

Daerah pelagis waduk merupakan daerah utama di mana plankton tumbuh dan berkembangbiak. Kelimpahan fitoplankton berkaitan erat dengan kandungan unsur hara $\mathrm{N}$ dan $\mathrm{P}$ perairan di mana unsur $N$ umumnya merupakan unsur pembatas pertumbuhannya. Di daerah sub tropis, suksesi fitoplankton sangat nyata terjadi menurut musim. Pada musim dingin, suksesi melibatkan flagelata kecil yang mampu beradaptasi pada suhu dan cahaya matahari yang rendah. Pada musim gugur terjadi pertumbuhan diatom yang diikuti oleh pertumbuhan cepat alga hijau. Pada musim panas populasi fitoplankton bervariasi dan berkaitan erat dengan status trofik perairan. Pada akhir musim panas dan permulaan musim semi, di perairan eutrofik perkembangan diatom kurang produktif sedangkan perkembangan alga hijau biru yang mampu memfiksasi nitrogen akan meningkat (Soil \& Water Conservation Society of Metro Halifax, 1999).

Kelimpahan fitoplankton menggambarkan karakteristik umum perairan waduk dan danau (Ryding \& Rast, 1989). Lebih lanjut dikatakan bahwa di perairan eutrofik, frekuensi pertumbuhan sesaat alga (alga blooms) lebih sering terjadi dengan kuantitas alga hijau dan alga hijau biru relatif lebih tinggi jika dibandingkan dengan di perairan oligotrofik. Di perairan eutrofik berdasarkan distribusi vertikalnya, alga umumnya hanya terdapat di permukaan, sedangkan di perairan oligotrofik terdistribusi sampai lapisan hipolimnion (atau dasar perairan) terutama pada perairan yang mengalami stratifikasi suhu. Distribusi harian alga di perairan eutrofik lebih terkonsentrasi di daerah tertentu jika dibandingkan dengan di perairan oligotrofik yang lebih meluas. Beberapa kelompok alga di perairan oligotrofik dicirikan oleh alga hijau (Desmids, Staurastrum) dan Diatoms (Tabellaria, Cyclotella) sedangkan di perairan eutrofik terdiri dari kelompok alga hijau biru (Anabaena, Aphanizomenon, Microcystis, Oscillatoria), dan Diatoms (Melosira, Fragilaria, Stephanodiscus, Asterionella).

Karakteristik umum keberadaan alga dalam kaitannya dengan peningkatan kesuburan perairan danau dikemukakan oleh Wetzel (1983). Di perairan oligotrofik dengan karakteristik perairan netral sampai sedikit alkalis dan kandungan unsur hara miskin biasanya alga yang dominan adalah Diatoms (terutama Cyclotella dan Tabellaria), Chrysophycean (Dinobryon, Mallomonas, Botryoccocus), Chlorococcal (Oocystis), Dinophyceae (Peridinium dan Ceratium spp.). Alga lain yang umumnya terdapat adalah Asterionella spp., Melosira spp., Chrysophyceans (Synura, Uroglena), Diatom (Tabellaria), serta fitoplankton berukuran kecil yang termasuk chrysophytes dan diatoms. Di perairan mesotrofik dengan perairan yang bersifat netral sampai sedikit alkalis didominasi oleh Dinophyceae (Peridinium dan Ceratium spp.) dan alga yang umumnya ditemukan adalah Glenodinium. Di perairan eutrofik dengan sifat perairan yang alkalis dan mengalami penyuburan, alga yang dominan adalah Diatom yang biasanya terdapat sepanjang tahun (terutama Asterionella spp., Fragilaria crotonensis, Synedra, Stephanodiscus, dan Melosira granulata), alga hijau biru (terutama Microcystis, Aphanizomenon, Anabaena). Alga lainnya adalah terutama dari alga hijau dan hijau biru selama musim panas, desmids (terdapat jika kandungan bahan organik terlarut sedikit tinggi) dan euglenophytes jika perairan mengalami penyuburan atau terpolusi bahan organik. Hutchinson (1967) mengembangkan indek fitoplankton yang berkaitan dengan transparansi, total biomassa seston, dan produktivitas perairan.

Biomassa fitoplankton biasanya diukur dengan cara mengukur jumlah klorofil-a di perairan yang merupakan pigmen fotosintesis sehingga dapat digunakan sebagai parameter untuk mengukur produksi fitoplankton. Rata-rata kandungan klorofil-a adalah $1,5 \%$ dari total bahan organik pada alga. Oleh karena itu, jika kandungan klorofil-a diketahui maka biomassa fitoplankton di perairan yang bersangkutan dapat diduga dengan mengalikannya dengan faktor 67 (Soil \& Water Conservation Society of Metro Halifax, 2000).

Potensi produksi Ikan di perairan danau sangat tergantung pada produktifitas primer perairan sehingga dapat digambarkan sebagal fungsi dari ratarata standing crop fitoplankton (Ogleby, 1976). Lebih lanjut dilaporkan bahwa hasil tangkapan Ikan berhubungan erat dengan produksi primer tahunan, standing crop fitoplankton dan indek morfoedafik perairan danau yang digambarkan dengan model persamaan logaritmik (Oglesby, 1977). 
Penelitian ini bertujuan untuk mengetahui struktur komunitas, distribusi spatio-temporal kelimpahan dan biomassa fitoplankton dalam hubungannya dengan potensi produksi ikan di Waduk Djuanda, Jawa Barat.

\section{BAHAN DAN METODE}

\section{Lokasi dan Waktu Pengambilan Contoh}

Penelitian dilakukan di lapiran atas perairan Waduk Ir. H. Djuanda, Jatiluhur selama delapan bulan yaitu dari bulan Mei sampai dengan Desember tahun 1998. Pengambilan contoh dilakukan satu kali setiap bulan di empat daerah pengamatan (Gambar 1) sebagai berikut:

1. Stasiun I, merupakan daerah budi daya ikan dalam keramba jaring apung dan daerah pemasukan Sungai Cilalawi.

2. Stasiun II, merupakan daerah genangan utama waduk.

3. Stasiun III, merupakan daerah transisi antara daerah pemasukan Sungai Citarum dan daerah genangan utama, yaitu daerah Pagadungan, Waduk Djuanda.

4. Stasiun IV, merupakan daerah pemasukan Sungai Citarum (pengeluaran Waduk Cirata) di daerah Warung Jeruk, Waduk Djuanda.

Pada setiap stasiun pengamatan ditentukan 3 sub stasiun secara horisontal dengan alur pengamatan mengarah ke bendungan utama dan di setiap sub stasiun ditetapkan 5 titik pengambilan contoh plankton secara vertikal, yaitu pada permukaan $\left(\begin{array}{ll}0 & \mathrm{~m}\end{array}\right)$, kedalaman $1 \mathrm{~m}, 2 \mathrm{~m}, 3 \mathrm{~m}, 4 \mathrm{~m}$, dan $5 \mathrm{~m}$. Dengan demikian, untuk setiap stasiun penelitian pada setiap bulan pengamatan akan terkumpul sebanyak 15 contoh plankton sehingga untuk seluruh waduk terkumpul sebanyak 60 contoh plankton.

\section{Pengambilan Contoh Plankton}

Pengambilan contoh plankton dilakukan dengan menggunakan van Dorn water sampler volume 3 liter pada setiap titik pengambilan contoh yang telah ditentukan. Contoh air yang diambil kemudian disaring dengan menggunakan jaring plankton ukuran mata 25

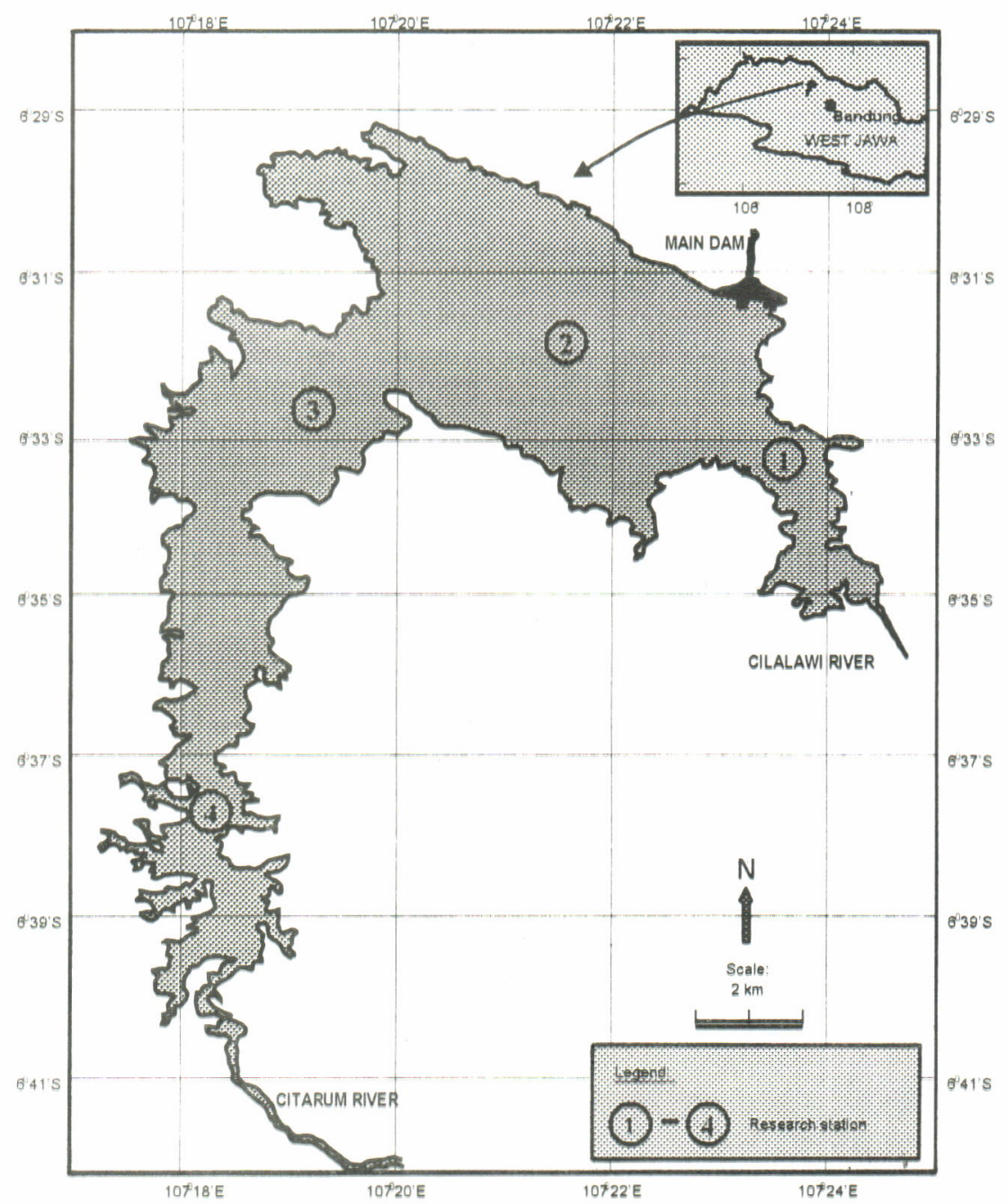

Gambar 1. Peta Waduk Ir. H. Djuanda dan empat stasiun pengamatan.

Figure 1. Map of Ir. H. Djuanda Reservoir and four research stations. 
$\mu \mathrm{m}$ menjadi contoh plankton dengan volume $35 \mathrm{ml}$. Contoh plankton diberi label sesuai dengan waktu dan titik pengambilan contoh, diawet dengan larutan Lugol dan kemudian dibawa ke laboratorium untuk diidentifikasi genusnya, dan dihitung kelimpahannya.

\section{Identifikasi Genus dan Penghitungan Kelimpahan Fitoplankton}

Identifikasi genus dilakukan di bawah mikroskop dengan pembesaran 40 kali menggunakan buku identifikasi dari Needham \& Needham (1963); Davis (1955); Edmonson (1959); dan Kamat (1976). Kelimpahan fitoplankton dihitung dengan menggunakan metoda Lackey Drop Microtransect Counting (APHA, 1989) dengan rumus:

$$
N=n \times \frac{a}{A} \times \frac{v}{v c} \times \frac{1}{V}
$$

di mana:

$$
\begin{array}{ll}
\mathrm{N} & \text { : jumlah total fitoplankton }(\mathrm{sel} / \mathrm{l}) \\
\mathrm{n} & \text { : jumlah rataan individu per lapang pandang } \\
\mathrm{a} & \text { : luas gelas penutup }\left(\mathrm{mm}^{2}\right) \\
\mathrm{V} & \text { : volume air terkonsentrasi }(\mathrm{ml}) \\
\mathrm{A} & \text { : luas satu lapang pandang }\left(\mathrm{mm}^{2}\right) \\
\mathrm{VC} & \text { : volume air di bawah gelas penutup }(\mathrm{ml}) \\
\mathrm{V} & \text { : volume air yang disaring }(\mathrm{I})
\end{array}
$$

Kelimpahan fitoplankton menurut genus dikelompokan ke dalam kelas berdasarkan klasifikasi Kamat (1976).

\section{Pengukuran Biomassa Fitoplankton}

Biomassa fitoplankton dihitung berdasarkan pada hasil pengukuran kandungan klorofil-a perairan di zona eufotik. Kandungan klorofil-a diukur menggunakan metoda spektrofotometer dengan :

$$
C h a=11,9 *(A 665-A 750) \times \frac{V}{L} \times \frac{1000}{S}
$$

di mana:

$\mathrm{Ch}_{\mathrm{a}}$ : kandungan klorofil-a $(\mu \mathrm{g} / \mathrm{l})$

A665 : Absorban pada panjang gelombang $665 \mathrm{~nm}$

A750 : Absorban pada panjang gelombang $750 \mathrm{~nm}$

$\mathrm{V} \quad$ : volume esktraksi aseton ( $\mathrm{ml}$ )

$\mathrm{L} \quad$ : panjang lintasan cahaya pada kuvet $(\mathrm{cm})$

$\mathrm{S} \quad$ : volume air contoh yang disaring $(\mathrm{ml})$

Biomassa fitoplankton dinyatakan dalam kandungan klorofil-a $\left(\mathrm{mg} / \mathrm{m}^{2}\right)$ menggunakan rumus sebagal berikut:

$\mathrm{B} \equiv 67 \times \mathrm{Cha}$ di mana:

$$
\begin{aligned}
& \text { biomassa fitoplankton }\left(\mathrm{g} / \mathrm{m}^{2}\right) \text { atau dalam } \\
& \left(\mathrm{mg} / \mathrm{m}^{2}\right)
\end{aligned}
$$

\section{Estimasi Potensi Produksi Ikan}

Potensi produksi ikan dihitung secara empiris dari hubungan antara hasil ikan (fisl, yield) dengan kandungan klorofil-a perairan seperti yang dikemukakan oleh Oglesby (1977) berdasarkan persamaan:

$$
\log Y f=-1,92+1,17 \log C h a
$$

di mana:

Yf :potensi produksi ikan dalam g (berat kering) $/ \mathrm{m}^{2} / \mathrm{th}$

Potensi produksi ikan dalam g (berat kering) $/ \mathrm{m}^{2} /$ th dikonversikan ke dalam satuan g (berat basah) $/ \mathrm{m}^{2} /$ th dengan asumsi bahwa berat ikan kering adalah $20 \%$ dari berat basah. Nilai potensi produksi ikan juga di konversikan ke dalam satuan $\mathrm{kg}$ (berat basah)/ha/th.

\section{Analisis Data}

Data kelimpahan fitoplankton untuk masingmasing kelas pada titik pengamatan yang sama dirata-ratakan menurut daerah dan bulan pengamatan. Data tersebut disajikan dalam bentuk tabel dan grafik, serta dianalisis secara deskriptif dengan membandingkannya baik menurut daerah pengamatan maupun bulan pengamatan. Data kelimpahan sepatio-temporal fitoplankton secara total berdasarkan stasiun dan bulan pengamatan diplot dalam bentuk grafik dan dihubungkan dengan fluktuasi tinggi permukaan air Waduk Djuanda. Data potensi produksi ikan dihitung untuk setiap bulan pengamatan kemudian dirata-ratakan dalam satu tahun.

\section{HASIL DAN BAHASAN}

\section{Komposisi Genus Fitoplankton}

Fitoplankton yang ditemukan di Waduk Djuanda, Jatiluhur selama pengamatan terdiri dari 30 genera yang termasuk ke dalam empat kelas, yaitu kelas Cyanophyceae 9 genera, kelas Chlorophyceae 11 genera, kelas Bacillariophyceae 8 genera, dan kelas Dinophyceae 2 genera (Tabel 1). Jumlah genera ini persis sama dengan yang ditemukan oleh Umar (2003) yang meneliti fitoplankton di daerah budi daya keramba jaring apung di perairan yang sama, namun lebih banyak jika dibandingkan dengan hasil penelitian pada tahun 1988 di perairan yang sama 
pula yang hanya menemukan 11 genera (Nuroniah \& Kartamihardja, 1988; Nastiti, 1989). Demikian pula, jumlah genera yang ditemukan lebih banyak jika dibandingkan dengan genera fitoplankton yang terdapat di Waduk Cirata dan Saguling (Costa-Pierce, 1992).

Nampaknya, hal ini berkaitan erat dengan meningkatnya proses penyuburan perairan Waduk Djuanda. Secara umum diketahui bahwa peningkatan kesuburan perairan di samping akan meningkatkan produktivitas perairan dalam pengertian kelimpahan dan biomassa fitoplankton juga akan meningkatkan keanekaragaman jenisnya. Pada tahun 1988, perairan Waduk Djuanda masih termasuk perairan dengan tingkat kesuburan sedang (mesotrofik) (Nuroniah \& Kartamihardja, 1988), namun sejak tahun 1998 tingkat kesuburan perairan waduk meningkat sehingga sekarang termasuk perairan yang subur sampai sangat subur (eutrofik-hypereutrofik) (Nastiti et al., 2001).

\section{Kelimpahan Fitoplankton}

Selama pengamatan, rata-rata kelimpahan fitoplankton total berkisar antara $2,86 \times 10^{5}-2,09 \times 10^{6}$ sel/l. Rata-rata kelimpahan fitoplankton tertinggi terjadi pada bulan Oktober, yaitu $1,52 \times 10^{6} \pm 1,19, \times 10^{5}$ sel/l dan terendah terjadi pada bulan Desember yaitu $5,86 \pm 0,68 \times 10^{5}$ sel/l (Tabel 2). Nilai kelimpahan fitoplankton tersebut lebih besar jika dibandingkan dengan kelimpahan fitoplankton di daerah budi daya keramba jaring apung pada bulan Maret dan April 2002 yang berkisar antara $9,15 \times 10^{4}-2,90 \times 10^{5} \mathrm{sel} / \mathrm{l}$ (Umar, 2003).

Tabel 1. Genera fitoplankton yang ditemukan di Waduk Djuanda selama pengamatan bulan Mei sampai dengan Desember

Table 1. The phytoplankton genera found in Djuanda Reservoir during observation from May to December

\begin{tabular}{|c|c|c|c|c|}
\hline \multirow{2}{*}{ No. } & \multicolumn{4}{|c|}{ Kelas dan Genus/Class and Genus } \\
\hline & Chlorophyceae & Cyanophyceae & Bacillariophyceae & Dinophyceae \\
\hline 1 & Coelastrum & Anabaena & Diatoma & Peridinium \\
\hline 2 & Zygnema & Oscillatoria & Fragillaria & Ceratium \\
\hline 3 & Scenedesmus & Lyngbia & Synedra & \\
\hline 4 & Straurastrum & Merismopedia & Cyclotella & \\
\hline 5 & Ulothrix & Gloeotrichia & Asterionella & \\
\hline 6 & Chlorella & Aphanizomenon & Tabellaria & \\
\hline 7 & Cosmarium & Microcystis & Navicula & \\
\hline 8 & Pediastrum & Gloeocapsa & Melosira & \\
\hline 9 & Eudorina & Phormidium & & \\
\hline 10 & Spirogyra & & & \\
\hline 11 & Desmids & & & \\
\hline
\end{tabular}

Tabel 2. Kelimpahan fitoplankton $\left(\times 10^{3} \mathrm{sel} / \mathrm{l}\right)$ di Waduk Ir. H. Djuanda pada permukaan air sampai kedalaman 5 m dari bulan Mei sampai Desember 1998

Table 2. Phytoplankton abundance $\left(\times 10^{3}\right.$ cell/I) in Ir. H. Djuanda Reservoir observed at the surface layer until $5 \mathrm{~m}$ depth from May to December 1998

\begin{tabular}{lcccccccc}
\hline \multicolumn{1}{c}{$\begin{array}{c}\text { Parameter } \\
\text { Parameters }\end{array}$} & \multicolumn{7}{c}{ Bulan Pengamatan/Month of observation } \\
\cline { 2 - 8 } & May & June & July & August & September & October & November & December \\
\hline $\begin{array}{l}\text { Rata-rata kelimpahan/ } \\
\text { Average density }\end{array}$ & $1.293,115$ & 866,707 & 969,192 & $1.138,182$ & $1.051,121$ & $1.519,309$ & 877,758 & 586,111 \\
$\begin{array}{l}\text { Simpangan baku/ } \\
\text { Standart deviation }\end{array}$ & 79,972 & 125,476 & 93,291 & 71,967 & 74,952 & 119,167 & 128,805 & 67,514 \\
$\begin{array}{l}\text { Nilai tengah/Median } \\
\text { Standar deviasi/ }\end{array}$ & $1.226,838$ & 817,846 & 911,622 & $1.130,884$ & $1.094,178$ & $1,420,564$ & 802,492 & 607,264 \\
$\begin{array}{l}\text { Standard deviation } \\
\text { Kelimpahan minimum/ }\end{array}$ & 195,892 & 307,352 & 228,516 & 176,282 & 183,595 & 291,899 & 315,506 & 165,376 \\
$\begin{array}{l}\text { Minimum abundance } \\
\text { Kelimpahan maximum/ }\end{array}$ & $1,050,192$ & 488,024 & 784,232 & 881,892 & 792,944 & $1,252,060$ & 531,736 & 285,696 \\
$\begin{array}{l}\text { Maximum abundance } \\
\text { Jumlah sample/ }\end{array}$ & $1,561,824$ & $1.326,204$ & $1,413,720$ & $1.366,596$ & $1,272,348$ & $2.086,136$ & $1,427,000$ & 744,554 \\
Number of samples & 60 & 60 & 60 & 60 & 60 & 60 & 60 & 60 \\
\hline
\end{tabular}

Pada umumnya, kelimpahan fitoplankton selama delapan bulan pengamatan untuk seluruh daerah pengamatan didominasi oleh genera dari kelas Chlorophyceae dan Bacillariophyceae yang kemudian diikuti oleh kelas Cyanophyceae, dan terakhir genera dari kelas Dinophyceae (Gambar 2). Tampak bahwa kelimpahan tertinggi fitoplankton dari semua kelas terjadi pada bulan Oktober, setelah itu kelimpahan fitoplankton menurun dan mencapai titik terendah pada bulan Desember. Kelimpahan fitoplankton yang 
kecuali pada bulan Juni dan Juli yang sedikit lebih rendah dari kelimpahan fitoplankton di stasiun III. Kelimpahan total fitoplankton di stasiun I dan III hampir sama, dan secara bergantian menempati urutan ketiga dan keempat.

Distribusi kelimpahan sepatio-temporal fitoplankton berdasarkan komposisi kelas dan kedalaman perairan tertera pada Gambar 3. Pada bulan Mei, Oktober, dan Desember distribusi vertikal kelimpahan fitoplankton tertinggi berada pada kedalaman lapisan perairan antara 2-5 m dengan rata-rata kisaran kelimpahan antara $400-600 \times 10^{3} \mathrm{sel} / \mathrm{l}$ yang didominasi oleh kelas Chlorophyceae dan Bacillariophyceae. Sebaliknya pada bulan Juni distribusi vertikal fitoplankton terkonsentrasi pada lapisan air permukaan sampai kedalaman $3 \mathrm{~m}$ dengan rata-rata kelimpahan antara $200-600 \times 10^{3}$ sel/l yang didominasi oleh kelas
Cyanophyceae, Chlorophyceae, dan Bacillariophyceae. Sedangkan pada bulan Juli, Agustus, September, dan Nopember kelimpahan fitoplankton terdistribusi hampir merata pada kolom air permukaan sampai kedalaman 5 meter yang didominasi oleh kelas Cyanophyceae, Bacillariophyceae, dan Chlorophyceae. Distribusi vertikal fitoplankton tersebut erat kaitannya dengan penetrasi cahaya, pembentukan termoklin, dan evaporasi (Wetzel \& Likens, 2000).

\section{Biomassa Fitoplankton}

Biomassa fitoplankton hanya diukur pada bulan Mei sampai dengan Oktober karena kesalahan teknis. Nilai biomassa fitoplankton yang diukur dari kandungan klorofil-a perairan tertera pada Tabel 3

Tabel 3. Biomassa fitoplankton perairan Waduk Djuanda selama pengamatan Mei sampai Oktober 1998 Table 3. $\quad$ Phytoplankton biomass at Djuanda Reservoir observation from May to October 1998

\begin{tabular}{lcccc}
\hline $\begin{array}{c}\text { Bulan } \\
\begin{array}{c}\text { Pengamatan } \\
\text { Month of } \\
\text { observation }\end{array}\end{array}$ & $\begin{array}{c}\text { Kisaran } \\
\text { Range }\end{array}$ & $\begin{array}{c}\text { Rata-rata } \pm \text { SE } \\
\text { Mean } \pm \text { SE }\end{array}$ & $\begin{array}{c}\text { Kisaran } \\
\text { Range }\end{array}$ & $\begin{array}{c}\text { Rata-rata } \pm \text { SE } \\
\text { Mean } \pm \text { SE }\end{array}$ \\
\hline May & $6,49-54,69$ & $24,20 \pm 8,24$ & $434,83-3664,23$ & $1.621,40 \pm 552,08$ \\
June & $6,49-47,65$ & $21,15 \pm 1,97$ & $434,83-3192,55$ & $1.417,10 \pm 131,99$ \\
July & $7,42-37,59$ & $20,23 \pm 5,59$ & $497,14-2518,53$ & $1.355,40 \pm 374,53$ \\
August & $6,50-25,09$ & $15,22 \pm 4,12$ & $435,50-1681,03$ & $1.019,70 \pm 276,04$ \\
September & $7,42-19,49$ & $12,05 \pm 2,60$ & $497,14-1305,83$ & $807,35 \pm 174,20$ \\
October & $6,50-18,56$ & $12,79 \pm 3,15$ & $435,50-1243,52$ & $856,93 \pm 211,05$ \\
November & $6,25-24,75$ & $14.25 \pm 3.45$ & $424,55-1596,04$ & $954,75 \pm 245,06$ \\
December & $6,74-25,65$ & $15.32 \pm 4.22$ & $446,05-1726,45$ & $1.026,44 \pm 256,14$ \\
\hline
\end{tabular}

Dari Tabel 3 terlihat bahwa rata-rata biomassa fitoplankton tertinggi terjadi pada bulan Mei yaitu $24,2 \pm 8,24 \mathrm{mgKlo}-\mathrm{a} / \mathrm{m}^{3}$ atau setara dengan $1621,4 \pm 552,08 \mathrm{mg} / \mathrm{m}^{2}$ dan terendah terjadi pada bulan September yaitu $12,05 \pm 2,60 \mathrm{mgKlo}-\mathrm{a} / \mathrm{m}^{3}$ atau setara dengan $807,35 \pm 174,20 \mathrm{mg} / \mathrm{m}^{2}$. Rata-rata biomassa fitoplankton tersebut lebih tinggi jika dibandingkan dengan biomassa fitoplankton di lokasi budi daya ikan dalam keramba jaring apung yang berkisar antara 0,017-26,66 $\mathrm{mgKlo}-\mathrm{a} / \mathrm{m}^{3}$ (Umar, 2003). Biomassa fitoplankton yang tinggi tersebut mengindikasikan bahwa perairan Waduk Djuanda merupakan perairan yang mengalami proses eutrofikasi yang tinggi. Mandaville (2000) mengklasifikasikan perairan danau berdasarkan kandungan klorofil-a di mana perairan eutrofik mempunyai kandungan klorofil-a antara $8-25 \mathrm{mg} / \mathrm{m}^{3}$ dengan kandungan klorofil-a maksimum 25-75 mg/m dan perairan hipereutrofik mempunyai kandungan klorofil-a lebih besar dari $75 \mathrm{mg} / \mathrm{m}^{3}$. Berdasarkan klasifikasi perairan tersebut, maka Waduk Djuanda termasuk perairan eutrofik sampai hipereutrofik.

\section{Potensi Produksi Ikan}

Potensi produks| Ikan bulanan berkisar antara $11,05-25,00 \mathrm{~kg} / \mathrm{ha} / \mathrm{bl}$ sedangkan potensi produksi ikan tahunan berkisar antara 132,7-300,1 $\mathrm{kg} / \mathrm{ha} / \mathrm{th}$ (Gambar 4), dengan rata-rata $198,3 \pm 60,5 \mathrm{~kg} / \mathrm{ha} / \mathrm{th}$ atau sebesar 1.645,825 ton/th. Potensi produksi ikan tersebut sangat bervariasi antara satu perairan dengan perairan lainnya dan sangat tergantung kepada komposisi jenis fitoplankton, zooplankton, dan struktur komunitas ikannya (Oglesby, 1977). Lebih lanjut dilaporkan bahwa transfer efisiensi dari produksi primer fitoplankton sampai biomassa ikan berkisar antara $0,002-1,5 \%$, di mana transfer efisiensi tertinggi terjadi di perairan waduk di Israel sedangkan yang terendah terjadi di perairan danau yang luas dan dalam daerah sub tropis. Potensi produksi ikan Waduk Djuanda tergolong tinggi sehingga waduk tersebut sangat potensial untuk pengembangan perikanan tangkap. Hasil tangkapan aktual yang telah dicapai pada tahun 2002 adalah sebesar 425 ton atau $51 \mathrm{~kg} / \mathrm{ha}$ (Sarnita, 2002) sehingga baru 26\% dari potensinya. Salah satu upaya yang dapat dilakukan untuk meningkatkan hasil tangkapan tersebut adalah dengan memanipulasi populasi ikan atau introduksi Ikan agar biomassa fitoplankton yang tersedia dapat dimanfaatkan oleh Ikan pemakan plankton, sepert| Ikan ringo (Thynichthys thynoides), atau Ikan mola (Hypopthalmistis molistrix). Dengan demikian, transfer efisiensi trofik dari produser primer (fitoplankton) ke biomassa Ikan akan meningkat. 


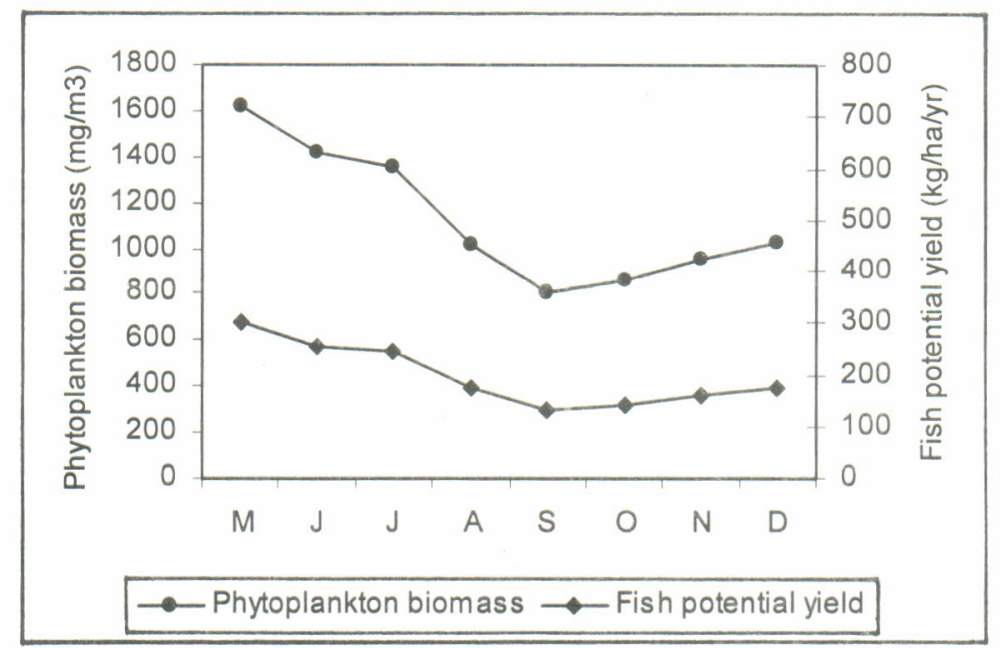

Gambar 4. Hubungan antara biomassa fitoplankton dengan potensi produksi ikan di Waduk Djuanda selama pengamatan bulan Mei sampai Desember 1998.

Figure 4. Relationship of phytoplankton biomass and fish potential yield in Djuanda Reservoir during the observation from May to December 1998.

\section{KESIMPULAN}

Di perairan Waduk Djuanda, terdapat 30 genera fitoplankton yang termasuk dalam kelas Chlorophyceae, Bacillariophyceae, Cyanophyceae, dan Dinophyceae dengan kelimpahan berkisar antara $2,86 \times 10^{5}-2,09 \times 10^{6} \mathrm{sel} / \mathrm{l}$, didominasi oleh genera dari kelas Chlorophyceae, Bacillariophyceae, dan Cyanophyceae. Secara horizontal distribusi kelimpahan fitoplankton tertinggi terdapat di stasiun IV (daerah pemasukan Sungai Citarum ke Waduk Djuanda) dan secara vertikal terdistribusi pada kolom air permukaan sampai kedalaman 5 meter kecuali pada bulan Mei, Juni, dan Oktober. Biomassa fitoplankton berkisar antara 24,2 $\pm 8,24 \mathrm{mgklo}-\mathrm{a} / \mathrm{m}^{3}$ atau setara dengan $1621,4 \pm 552,08 \mathrm{mg} / \mathrm{m}^{2}$ dan $12,05 \pm 2,60 \mathrm{mgklo}-\mathrm{a} / \mathrm{m}^{3}$ atau setara dengan $807,35 \pm 174,20 \mathrm{mg} / \mathrm{m}^{2}$. Biomassa yang tinggi tersebut menjadikan Waduk Djuanda sebagai perairan eutrofik-hipereutrofik dengan potensi produksi ikannya diperkirakan antara 132,7-300,1 kg/ha/th dengan ratarata $198,3 \pm 60,5 \mathrm{~kg} / \mathrm{ha} / \mathrm{th}$, sedangkan hasil tangkapan aktual pada tahun 2002 sebesar 425 ton atau sekitar $26 \%$ dari potensinya. Manipulasi populasi ikan dengan cara introduksi ikan pemakan plankton merupakan salah satu upaya yang dapat dilakukan untuk meningkatkan transfer efisiensi dari biomassa fitoplankton menjadi biomassa ikan.

\section{DAFTAR PUSTAKA}

APHA (American Public Health Association). 1989. Standard methods for the examination of water and waste water including bottom sediment and sludges. $12^{\text {th }}$. American Pub. Health Assoc, Inc. New York.
Carmichael, W.W. 1992. A status report on planktonic cyanobacteria (Blue-Green Algae) and their toxins. USEPA \# EPA/600/R-92/079, 141pp

Costa-Pierce, B.A. 1992. Multiple regression analysis of plankton and water-quality relationships as affected by sewage inputs and cage aquaculture in eutrophic, tropical reservoir. In De Silva, S.S. (ed). Reservoir Fisheries of Asia. Proc. of the $2^{\text {nd }}$ Asian Reservoir Workshop Held in Hangzhou, People's Republic of China, 15-19 Oktober 1990. IDRC, p: 38--48.

Davis, G.C. 1955. The Marine and freshwater plankton. Michigan State University Press. USA.

Edmondson, W.T. 1959. Freshwater biology, $2^{\text {nd }}$ Ed. John Willey \& Son Inc. New York, 1248 pp.

Hutchinson, G.E. 1967. A treatise on limnology. Vol-II. Introduction to lake biology and the limnoplankton. John Wiley \& Sons, $1115 \mathrm{pp}$.

Kamat, N.D. 1976. A text book of algae. S Chand and Company Ltd. Ram Nagar. New Delhi, 159 pp.

Omandaville, S.M. 2000. Limnology-eutrophication and chemistry, carrying capacities, loadings, benthic ecology, and comparative data. Soil \& Water Conservation Society of Metro Halifax. Synopses 1, 2, 3, 13 and 14, 210 pp.

Moriarty C.M. \& D.J.W. Moriarty. 1973. Quantitative estimation of the daily ingestion of phytoplankton by Tilapia nilotica and Haplochromis nigripinnus in lake George, Uganda. J. Zool., 171: 15--23. 
Nastiti, A.S., Krismono, \& E.S. Kartamihardja. 2001. Daya dukung perairan Waduk Jatiluhur untuk budi daya ikan dalam keramba jaring apung. Jurnal Penelitian Perikanan Indonesia, 7(2): 14--21.

Nastiti, A.S. 1989. Suatu pendugaan status air perairan Waduk Juanda di daerah Pasir Kole pada bulan Juni tahun 1988 ditinjau dari aspek sifat fisika kimiawi air dan fitoplankton. Tesis Magister Sains, Fakultas Pascasarjana. IPB. Bogor, 82 pp

Needham, J.G \& P.R. Needham. 1963. A guide to the study of freshwater biology. Fifth ed. Holden Day Inc. San Fransisco. 108 pp.

Nuroniah, S. \& E. S. Kartamihardja. 1988. Studi pendahuluan produktivitas primer di Waduk Jatiluhur, Jawa Barat. Buletin Penelitian Perikanan Darat. Balitkanwar. Bogor, p: 22--28.

Ogleby, R.T. 1976. Fish yield as a monitoring parameter and its prediction for lakes, p: 195--205. In J.S. Alabastor (ed). Biological of inland fisheries. Applied Science Pub. Ltd. London, 226 pp.

Ogleby, R.T. 1977. Relationship of fish yield to lake phytoplankton standing crop, production, and morphoedaphic fakctors. J. Fish. Res. Board Can, 34: 2271--2279.

Ryding, S.O. \& W. Rast. 1989. The control of eutrophication of lakes and reservoirs. man and the biosphere series. Vol.1. UNESCO. The Parthenon Publishing Group, 314 pp

Sarnita, A.S. 2002. Pemacuan stok ikan patin (Pangasius hypopthalmus) di waduk Juanda, Jatiluhur. Lap. Hasil Penelitian Pusat Riset Perikanan Tangkap, Badan Riset Kelautan dan Perikanan, $15 \mathrm{pp}$.

Soil \& Water Conservation Society Of Metro Halifax 1999. Phytoplankton (of freshwaters) http:/www.region.halifax.ns.ca. 20 Januari 2003.

Soil and Water Conservation Society of Metro Halifax. 2000. Chlorophyll-a an intro and an analytical methodology. http:/www.region.halifax.ns.ca. 20 Januari 2003.

Umar, C. 2003. Struktur komunitas dan kelimpahan fitoplankton dalam kaitannya dengan muatan unsur hara (nitrogen dan fosfor) dari budi daya ikan dalam keramba jaring apung di Waduk Ir. H. Juanda, Jatiluhur Jawa Barat. Thesis. Master Sain. Pascasarjana IPB. Bogor.

Wetzel, R.G. \& G.E. Likens. 2000. Limnological analyses. W.B Saunder Co. Philadelphia, 357 pp.

Wetzel, R.G., 1983. Limnology. Saunders College Publishing, $860 \mathrm{pp}$. 